J. Lake Sci. (湖泊科学) , 2017, 29(6): 1386-1397

DOI 10. 18307/2017. 0611

(C) 2017 by Journal of Lake Sciences

\title{
巢湖流域水生植物多样性”
}

\author{
王金霞 ${ }^{1}$, 孟炜淇 ${ }^{1}$, 李国祥 ${ }^{1}$, 高俊峰 $^{2}$, , 蔡永久 $^{2}$, 张庭廷 $^{1}$, 刘 $^{\text {坤 }}{ }^{\text {*** }}$ \\ (1: 安徽师范大学生命科学学院,重要生物资源保护与利用研究安徽省重点实验室,芜湖 241000) \\ (2: 中国科学院南京地理与湖泊研究所,南京 210008)
}

\begin{abstract}
摘 要: 水生植物在浅水湖泊或河流生态系统中具有非常重要的作用. 通过 2 次野外实地调查, 对巢湖流域水生植物物 种的区系组成和多样性进行初步分析. 结果表明:巢湖流域水生植物共有 43 科 85 属 123 种 (含种下分类单位,下同), 其 中硕类植物有 5 科 6 属 6 种, 被子植物 38 科 77 属 117 种, 在被子植物中双子叶植物 25 科 39 属 63 种, 单子叶植物 13 科 40 属 54 种. 水禾 (Hygroryza aristata) 为安徽省首次记录; 以禾本科 (Gramineae)、蓼科 (Polygonaceae) 和莎草科 (Cyperaceae) 等为优势科; 以蓼属 (Polygonum)、眼子菜属 (Potamogeton) 和菱属 (Trapa) 等为优势属, 属的组成比较分散, 塞种属和单种属占总属数的 $96.5 \%$; 以喜早莲子草 (Alternanthera philoxeroides)、芦苇 (Phragmites australis)、淔草 (Potamogeton crispus)、菱( Trapa sp.)、金鱼藻 (Ceratophyllum demersum) 和黑藻 (Hydrilla verticillata) 等为优势种; 从分布区类型 看,在科级水平上有 6 个类型,科的分布区类型以世界广布最多,达 $55.81 \%$, 热带分布的科 (11 科) 多于温带分布的科 $(8$ 科); 在属级水平上有 13 个类型, 属的分布区类型以世界广布最多 (36.47\%), 其次是泛热带分布 $(20.0 \%)$; 从不同流域来 看, 水生植物物种多样性以白石天河流域最高, 店埠河南汁河流域最低, 这可能与南游河水质污染比较严重有一定的 关系.
\end{abstract}

关键词: 巢湖流域;水生植物;多样性

\section{Diversity of aquatic plants in Chaohu Basin}

WANG Jinxia ${ }^{1}$, MENG Weiq $^{1}$, LI Guoxiang ${ }^{1}$, GAO Junfeng ${ }^{2}$, CAI Yongjiu $^{2}$, ZHANG Tingting $^{1}$ \& LIU Kun ${ }^{1 * *}$

(1: Anhui Provincial Key Laboratory of the Conservation and Exploitation of Biological Resources, College of Life Science, Anhui Normal University, Wuhu 241000, P.R.China)

(2: Nanjing Institute of Geography and Limnology, Chinese Academy of Sciences, Nanjing 210008, P.R.China)

Abstract: The abundance and composition of aquatic plants have great effect on shallow lakes or river ecosystems. The diversity of aquatic plants from rivers and lakeshore zone in Chaohu Basin were investigated in April and July, 2013. The flora of aquatic plants was analyzed and the species diversity was assessed. Results showed that: The species number of aquatic plants was relatively high. There were total 123 species belonged to 43 families and 85 genera, among of which there were about 5 families, 6 genera, 6 species in Pteridophyta, 25 families, 39 genera, 63 species in Dicotyledoneae and 13 families, 40 genera, 54 species in Monocotyledoneae. Hygroryza aristata was first recorded in Anhui Province. Gramineae, Polygonaceae and Cyperaceae were the dominant families. The preponderant genera included Polygonum, Potamogeton and Trapa. The percentage of the genera including only 1 species or 2-4 species accounted for 96.5\%. The dominant species were Alternanthera philoxeroides, Phragmites australis, Potamogeton crispus, Trapa sp., Ceratophyllum demersum, and Hydrilla verticillata. At family level, there were 6 distribution types. The proportion of the cosmopolitan type was highest and reached $55.81 \%$, and the tropic elements ( 11 families ) were more than temperate ones ( 8 families). At genus level, there were 13 distribution types. The cosmopolitan type was $36.47 \%$ and the pantropic type was $20.0 \%$. Alpha diversity was highest in the Baishitian River, and was lowest in the Nanfeihe River. Serious water pollution could be

* 国家水体污染控制与治理科技重大专项( 2012ZX07501-002-008)、安徽省皖江城市带退化生态系统的恢复与重建 协同创新中心项目和国家自然科学基金项目(31170443)联合资助. 2016-11-04 收稿; 2017-03-05 收修改稿. 王金霞(1986 ), 女, 硕士,实验师;E-mail : wangjinxia945@126.com.

** 通信作者;E-mail: hudixiao@126.com. 
the main reason accounting for the lower species diversity in the Nanfeihe River.

Keywords: Chaohu Basin; aquatic plant; diversity

巢湖位于安徽省中部, 是我国五大淡水湖泊之一 ${ }^{[1]}$, 也是长江中下游典型的大型浅水湖泊, 其流域面积 约为 $1.3 \times 10^{4} \mathrm{~km}^{2}$, 流域内河流水系密度较大、纵横交错, 共有大小 33 条出人湖河流, 主要包括杭埠河一丰乐 河、白石天河、店埠河一南淝河、柘臬河一夏阁河、派河、裕溪河等 7 大水系 ${ }^{[2-3]}$. 水生植物是水生生态系统的 重要组成部分, 对水生生态系统平衡的维持具有非常重要的作用 ${ }^{[4]} .2010-2011$ 年安徽省进行了第二次湿 地生物多样性调查工作, 对安徽省内的湿地植物资源有了初步的了解 ${ }^{[5]}$. 目前有关巢湖流域的调查研究主 要集中在水体污染方面 ${ }^{[6-7]}$, 对水生植物多样性的研究相对比较少, 仅有少数学者对人湖河流 (如十五里河) 等河口湿地植物及湖滨带植物进行了研究 ${ }^{[8-10]}$, 对整个巢湖流域水生植物多样性的研究则未见报道. 由于巢 湖流域水质下降, 近几十年巢湖水生植物分布面积不断萎缩, 水生植物群落向单一化发展 ${ }^{\left[{ }^{[0]}\right.}$. 水生植物的 种类组成及物种多样性在一定程度上可直观地反映出湖泊、河流等水体的受污染程度. 研究水生植被的种 类组成、区系特征、群落结构及生物多样性等特征, 对合理利用湖泊及河流水生植物资源, 改善湖泊及河流 水质具有重要的现实意义. 本文将重点研究巢湖流域主要河流及湖滨带水生植物区系组成及群落结构的空 间差异, 为流域内水生植物资源开发与保护提供生物学依据,为巢湖流域的生态环境保护提供基础资料.

\section{1 研究方法}

\section{1 样点设置与调查}

根据巢湖流域主要河流分布情况, 共布设了 186 个水生植物调查样点, 覆盖整个研究区域的不同流域 及巢湖湖滨带, 各流域的样点分布情况为: 白石天河流域( I ) 5 个样点、巢湖湖滨带( II ) 38 个样点、店埠河 南汁河流域 ( III) 25 个样点、杭埠河丰乐河流域 ( IV) 50 个样点、派河流域 ( V) 6 个样点、西河裕溪河流域 ( VI) 38 个样点、兆河流域 (VII) 16 个样点、柘臬河夏阁河流域 (VIII) 8 个样点,采样点位置见图 1.

2013 年 4 月 (春季) 和 7 月 (夏季) 对样点进行两次野外调查. 采样过程中由于部分样点未能到达, 4 月 实际调查了 171 个样点, 7 月实际调查了 182 个样点. 关于水生植物的界定参考 Cook 等 ${ }^{[11]}$ 的定义. 在每个 调查点位布设 5 个 $1 \mathrm{~m} \times 1 \mathrm{~m}$ 的样方, 水生植物群落调查和采样方法参考文献[12-14], 在设定的样方中, 分 别记录种名以及物种的高度、盖度、株数、多度及生物量等,并记录下样方的经纬度、海拔等.

\section{2 数据处理}

物种多样性的测度方法参考文献[15-16], 对水生植物多样性的测定采用物种丰富度指数和 $\alpha$ 多样性 测定方法.

物种丰富度指数 $S=$ 样地内出现的物种数.

$\alpha$ 多样性测定方法:

$$
\begin{gathered}
\text { Shannon-Wiener 多样性指数 }=-\sum_{i=1}^{S} p_{i} \ln p_{i} \\
\text { Simpson 多样性指数 }=1-\sum_{i=1}^{S} p_{i}^{2} \\
\text { Pielou 均匀度指数 }=H / \ln S
\end{gathered}
$$

式中, $p_{i}$ 为第 $i$ 种的重要值; $S$ 为样地内出现的物种数.

\section{2 结果}

\section{1 巢湖流域水生植物区系多样性}

2.1.1 全流域水生植物种类组成 经 2013 年 4 月和 7 月两次野外调查, 共发现巢湖流域水生植物 43 科 85 属 123 种 (含种下分类阶元) (附录), 其中撂类植物有 5 科 6 属 6 种, 被子植物 38 科 77 属 117 种. 在被子植 物中双子叶植物 25 科 39 属 63 种, 单子叶植物 13 科 40 属 54 种.

科的大小按属数多少统计表明, 在巢湖流域 43 科水生植物中, 含 4 属以上的科有 4 个, 即禾本科 18 属、 菊科 5 属、莎草科 5 属、水鳖科 4 属等; 含 $2 \sim 3$ 属的科有 12 个, 占总科数的 $27.9 \%$, 属数 26 个, 占总属数的 


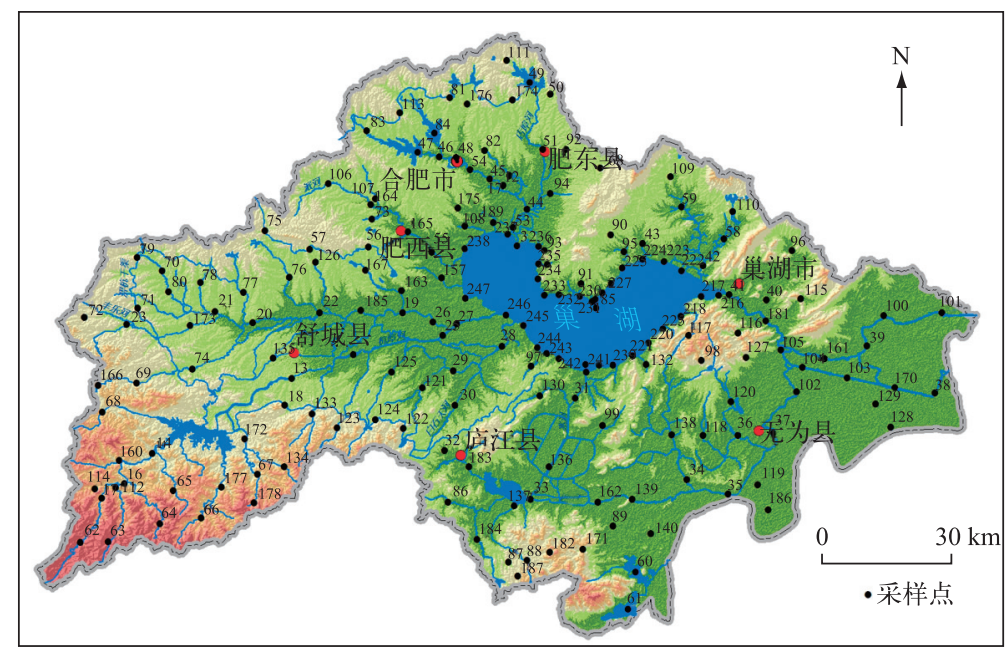

图 1 巢湖流域水生植物采样点示意

Fig.1 Distribution of sampling sites of aquatic plants in Chaohu Basin

$30.6 \%$;含 1 属的科有 27 个,占总科数的 $62.8 \%$,属数 27 个,占总属数的 $31.8 \%$.

科的大小按种数多少统计表明, 在巢湖流域 43 科水生植物中, 含 10 种以上的水生植物大科有 3 个, 即 禾本科 18 属 19 种,苶科 2 属 12 种,莎草科 5 属 10 种; 含 $5 \sim 9$ 种的较大科有 5 个, 即十字花科 6 种, 毛莨科 5 种, 菱科 5 种, 菊科 5 种, 眼子菜科 5 种. 以上 8 科共含种数有 67 种, 占总种数的 $54.4 \%$; 含 $2 \sim 4$ 种的小型科 共有 15 科,占总科数的 $34.9 \%$, 共有 36 种, 占总种数的 $29.3 \%$; 单种科共有 20 科 20 种, 占总科数的 $46.5 \%$, 占总种数的 $16.3 \%$.

巢湖流域水生植物属的大小按种数多少统计, 含 5 种以上的属有 3 个, 共有 20 种, 分别为蓼属 10 种, 眼 子菜属 5 种, 菱属 5 种; 含 $2 \sim 4$ 种的属有 15 属, 占总属数的 $17.7 \%$, 共计 36 种, 占总种数的 $29.3 \%$; 67 属为单 种属, 占总属数的 $78.8 \%$, 共 67 种, 占总种数的 $54.5 \%$.

表 1 巢湖湖滨带及主要子流域水生植物种类组成

Tab.1 The composition of aquatic plants from rivers and lakeshore zone in Chaohu Basin

\begin{tabular}{|c|c|c|c|}
\hline 主要流域( 编号) & 科数 & 属数 & 种数 \\
\hline 白石天河流域 ( I ) & 21 & 28 & 33 \\
\hline 巢湖湖滨带( II ) & 27 & 42 & 53 \\
\hline 店埠河南淝河流域 ( III ) & 25 & 42 & 58 \\
\hline 杭埠河丰乐河流域( IV) & 38 & 71 & 94 \\
\hline 派河流域( V) & 13 & 23 & 24 \\
\hline 西河裕溪河流域 ( VI) & 31 & 51 & 70 \\
\hline 兆河流域 ( VII ) & 24 & 39 & 52 \\
\hline 柘者河夏阁河流域 ( VIII) & 19 & 27 & 34 \\
\hline
\end{tabular}

2.1.2 巢湖湖滨带及主要子流域水生植物种类组 成 从巢湖湖滨带及主要子流域水生植物种类 组成情况来看 (表 1), 杭埠河丰乐河流域水生植 物种类最多, 共 94 种, 隶属于 38 科、71 属; 其次 是西河裕溪河流域, 共有 70 种, 隶属于 31 科、51 属; 派河流域种类最少, 仅 13 科 23 属 24 种.

2.1.3 巢湖流域水生植物优势种 某一个调查样 点中重要值位于第一位的物种即为该调查样点 的优势种. 巢湖流域 4 月和 7 月出现次数位于前 10 位的优势种见表 2 , 可见无论是 4 月还是 7 月 喜旱莲子草均为巢湖流域最具优势的水生植物, 4 月共有 52 个样点的水生植物优势种为喜旱莲 子草, 占样点总数的 $31.3 \%$; 7 月共有 59 个样点

的水生植物优势种为喜旱莲子草, 占样点总数的 $33.5 \%$. 在 4 月份, 菹草也是巢湖流域具有优势的水生植物, 仅次于喜旱莲子草, 共有 34 个样点的优势种为该物种, 占样点总数的 $20.5 \%$; 其次是芦苇, 共有 23 个样点的 优势种为该物种, 占样点总数的 $13.9 \%$; 其他优势物种包括曧草、微齿眼子菜、菖蒲、穗状狐尾藻、香蒲等. 在 7 月份, 菹草一般已经腐烂分解, 芦苇取代菹草, 成为仅次于喜旱莲子草的优势物种, 共有 28 个样点的优势 种为该物种, 占样点总数的 $15.9 \%$; 其次是菱角, 是 15 个样点的优势物种, 占样点总数的 $13.9 \%$; 其他优势物 
种包括金鱼藻、曧草、黑藻、双穗雀稗、竹叶眼子菜、水鳖、穗状狐尾藻等. 可以看出,整个巢湖流域的水生植 物优势种主要是喜旱莲子草、芦苇、蕰草、菱、金鱼藻、曧草和黑藻等.

表 2 巢湖流域 4 月和 7 月水生植物优势种

Tab.2 The dominant species of aquatic plants in April and July from Chaohu Basin

\begin{tabular}{|c|c|c|c|c|c|}
\hline \multicolumn{3}{|c|}{4 月 } & \multicolumn{3}{|c|}{7 月 } \\
\hline 优势种 & 样点数 & 频度/\% & 优势种 & 样点数 & 频度/\% \\
\hline 喜旱莲子草 & 52 & 31.3 & 喜旱莲子草 & 59 & 33.5 \\
\hline 菹草 & 34 & 20.5 & 芦苇 & 28 & 15.9 \\
\hline 芦苇 & 23 & 13.9 & 菱 & 15 & 8.5 \\
\hline 鷊草 & 9 & 5.4 & 金鱼藻 & 10 & 5.7 \\
\hline 微齿眼子菜 & 6 & 3.6 & 虉草 & 7 & 4.0 \\
\hline 石菖蒲 & 4 & 2.4 & 黑藻 & 6 & 3.4 \\
\hline 菖蒲 & 3 & 1.8 & 双穗雀稗 & 6 & 3.4 \\
\hline 齿果酸模 & 3 & 1.8 & 竹叶眼子菜 & 6 & 3.4 \\
\hline 穗状狐尾藻 & 3 & 1.8 & 水鳖 & 5 & 2.8 \\
\hline 香蒲 & 3 & 1.8 & 穗花狐尾藻 & 5 & 2.8 \\
\hline
\end{tabular}

2.1 .4 巢湖流域水生植物区系特征 参考《世界种子植物科的分布区类型系统》 ${ }^{[17]}$ 的划分, 可将巢湖流域水 生植物 43 科划分为 6 种分布区类型 (表 3), 可归并为世界分布科、热带分布科和温带分布科. 世界分布科共 计 24 个, 占该区系总科数的 $55.81 \%$. 热带分布科共有 11 个, 占该总科数的 $25.58 \%$, 其中, 绝大多数是泛热 带分布科. 温带成分科共有 8 个, 占该区系总科数的 $18.60 \%$, 其中主要是北温带分布科, 共有 6 个.

根据《中国植物志》第一卷 ${ }^{[18]}$ 蕨类植物属的分布区类型和吴征镒等 ${ }^{[19]}$ 关于中国种子植物属的分布区类 型的划分, 可将巢湖流域水生植物划分为 13 种分布区类型, 分别阐述如下 (表 3 ):

(1) 世界分布:在巢湖流域共有 31 个属, 占总属数的 $36.47 \%$, 该类型以温带分布的草本植物为主, 水生 或沼生的有槐叶萍属、眼子菜属、芦苇属等;湿生的有苶属、酸模属等.

（2）泛热带分布:本类型有 17 属, 占总属数的 $20.00 \%$, 常见的有莲子草属、苦草、假稻属、雀稗属、狗牙 根属等.

(3) 热带亚洲和热带美洲间断分布: 本类型在巢湖流域仅有过江藤属、凤眼莲属.

（4）旧世界热带分布: 本类型有 3 属, 常见的有水竹叶属、香茶菜属和水鳖属.

(5) 热带亚洲至热带大洋洲分布: 本类型有 2 属, 即黑藻属和通泉草属.

(6) 热带亚洲至热带非洲分布:本类型在巢湖流域有 1 属, 即荩草属.

(7) 热带亚洲分布:本类型在巢湖流域有 2 属, 即水禾属和芋属.

（8) 北温带分布:在巢湖流域有 13 属, 占总属数的 $15.29 \%$. 常见的有嗝草属、稗属、水毛莨属、蒿属等属.

(9) 东亚和北美间断分布:这一类型在巢湖流域水生植物区系中有菰属、菖蒲属、扯根菜属、鹅肠菜属、 莲属共 5 属.

(10)旧世界温带分布:本类型在巢湖流域有 3 属, 它们是菱属、水芹属和我观草属.

(11) 温带亚洲分布:本类型在巢湖流域较贫乏,仅马兰属.

(12) 东亚分布:本类型有苂属、茶菱属、盒子草属和荻属共 4 属.

(13) 中国特有分布:本类型在巢湖流域水生植物中有虾须草属 1 属.

巢湖流域水生植物中, 属数最多的为世界广布型, 共 31 属, 其次是泛热带分布和北温带分布, 分别有 17 属和 13 属. 巢湖流域水生植物中, 热带分布属 ( $2 \sim 7$ 型) 共有 27 属, 具有温带性质的温带分布属 ( $8 \sim 13$ 型) 也共有 27 属, 温带类型与热带类型相当.

\section{2 水生植物的多样性}

2.2.1 全流域水生植物物种多样性及空间分布格局 巢湖流域 4 月和 7 月各样点的水生植物物种多样性并 
不丰富,4 月和 7 月物种丰富度指数的平均值分别为 5.940 和 6.527 ; Shannon-Wiener 指数的平均值分别为 1.486 和 1.523 , 与 4 月相比, 7 月各样点物种丰富度指数和 Shannon-Wiener 指数的平均值略高一些, 但 Simpson 优势度指数和 Pielou 均匀度指数的平均值要比 4 月略低一点, 从总体上看, 7 月各样点水生植物物 种多样性要高一些 (表 4).

表 3 巢湖流域水生植物科、属的分布区类型

Tab.3 The distribution types of families and genera in the flora of aquatic plants in Chaohu Basin

\begin{tabular}{lcccc}
\hline 分布区类型 & 科数 & 占总科数 $/ \%$ & 属数 & 占总属数 $/ \%$ \\
\hline 1.世界广布 & 24 & 55.81 & 31 & 36.47 \\
2.泛热带分布 & 10 & 23.26 & 17 & 20.00 \\
3.东亚(热带、亚热带) 及热带南美间断分布 & - & - & 2 & 2.35 \\
4.旧世界热带分布 & - & - & 3 & 3.53 \\
5.热带亚洲至热带大洋洲分布 & - & - & 2 & 2.35 \\
6.热带亚洲至热带非洲分布 & 1 & 2.33 & 1 & 1.18 \\
7.热带亚洲分布 & - & - & 2 & 2.35 \\
8.北温带分布 & 6 & 13.95 & 13 & 15.29 \\
9.东亚和北美间断分布 & 1 & 2.33 & 5 & 5.88 \\
10. 旧世界温带分布 & 1 & 2.33 & 3 & 3.53 \\
11. 温带亚洲分布 & - & - & 1 & 1.18 \\
12. 东亚分布 & - & - & 4 & 4.71 \\
13. 中国特有分布 & - & - & 1 & 1.18 \\
合计 & 43 & 100 & 85 & 100 \\
\hline
\end{tabular}

表 4 巢湖流域各样点水生植物物种多样性分析

Tab.4 The species diversity indexes of aquatic plants in Chaohu Basin

\begin{tabular}{lccccc}
\hline \multirow{2}{*}{ 物种多样性指数 } & \multicolumn{2}{c}{ 均值 \pm 标准差 } & & \multicolumn{2}{c}{ 最大值 } \\
\cline { 2 - 3 } \cline { 5 - 6 } & 4 月 & 7 月 & 月 & 7 月 \\
\hline 物种丰富度指数 & $5.940 \pm 2.726$ & $6.527 \pm 3.401$ & & 13.000 & 15.000 \\
Shannon-Wiener 指数 & $1.486 \pm 0.571$ & $1.523 \pm 0.651$ & 2.436 & 2.523 \\
Simpson 优势度指数 & $0.693 \pm 0.223$ & $0.691 \pm 0.246$ & & 0.902 & 0.913 \\
Pielou 均匀度指数 & $0.834 \pm 0.238$ & $0.819 \pm 0.261$ & & 1.000 & 0.993 \\
\hline
\end{tabular}

从巢湖流域各样点水生植物物种多样性的空间分布格局来看 (图 2), 西部丘陵区调查样点的物种多样 性在 4 和 7 月相对高一些, 店埠河南汁河流域和巢湖湖滨带的物种多样性相对低一些, 在南洞河的部分采样 点位没有发现水生植物或仅有喜旱莲子草,物种多样性很低.

统计表明, 4 月各样点调查发现的水生植物物种数在 $0 \sim 13$ 之间, 分布有 5 9 个种的样点有 108 个, 占 样点总数的 $63.16 \%$, 共有 18 个采样点的物种数小于或等于 2 种, 物种多样性极低, 其中店埠河南淍河流域 有 8 个, 占该流域调查总样点数的 $30.77 \%$; 巢湖湖滨带有 5 个, 占该区域调查总样点数的 $25 \% .7$ 月各样点 调查发现的水生植物物种数在 0 15 之间, 分布有 5 9 个种的样点有 99 个, 占样点总数的 $54.40 \%$, 共有 27 个采样点的水生植物物种数小于或等于 2 种, 其中巢湖湖滨带有 13 个, 占该区域调查样点总数的 $40.63 \%$; 店埠河南淝河流域共有 10 个,占该流域调查样点总数的 $41.67 \%$.

4 月各样点 Shannon-Wiener 指数在 $0 \sim 2.436$ 之间, 7 月各样点 Shannon-Wiener 指数在 $0 \sim 2.523$ 之间, 总 体上 7 月各样点的 Shannon-Wiener 指数值要略高于 4 月. 与物种丰富度相似, 店埠河南淝河流域和巢湖湖 滨带部分采样点的 Shannon-Wiener 指数也很低.

2.2.2 巢湖湖滨带及主要子流域水生植物物种多样性 物种多样性通过统计发现, 巢湖湖滨带和 7 个主要流 域 4 月水生植物物种多样性差异比较明显(图 3), 水生植物物种数在不同流域中变化较大, 8 个主要区域内 

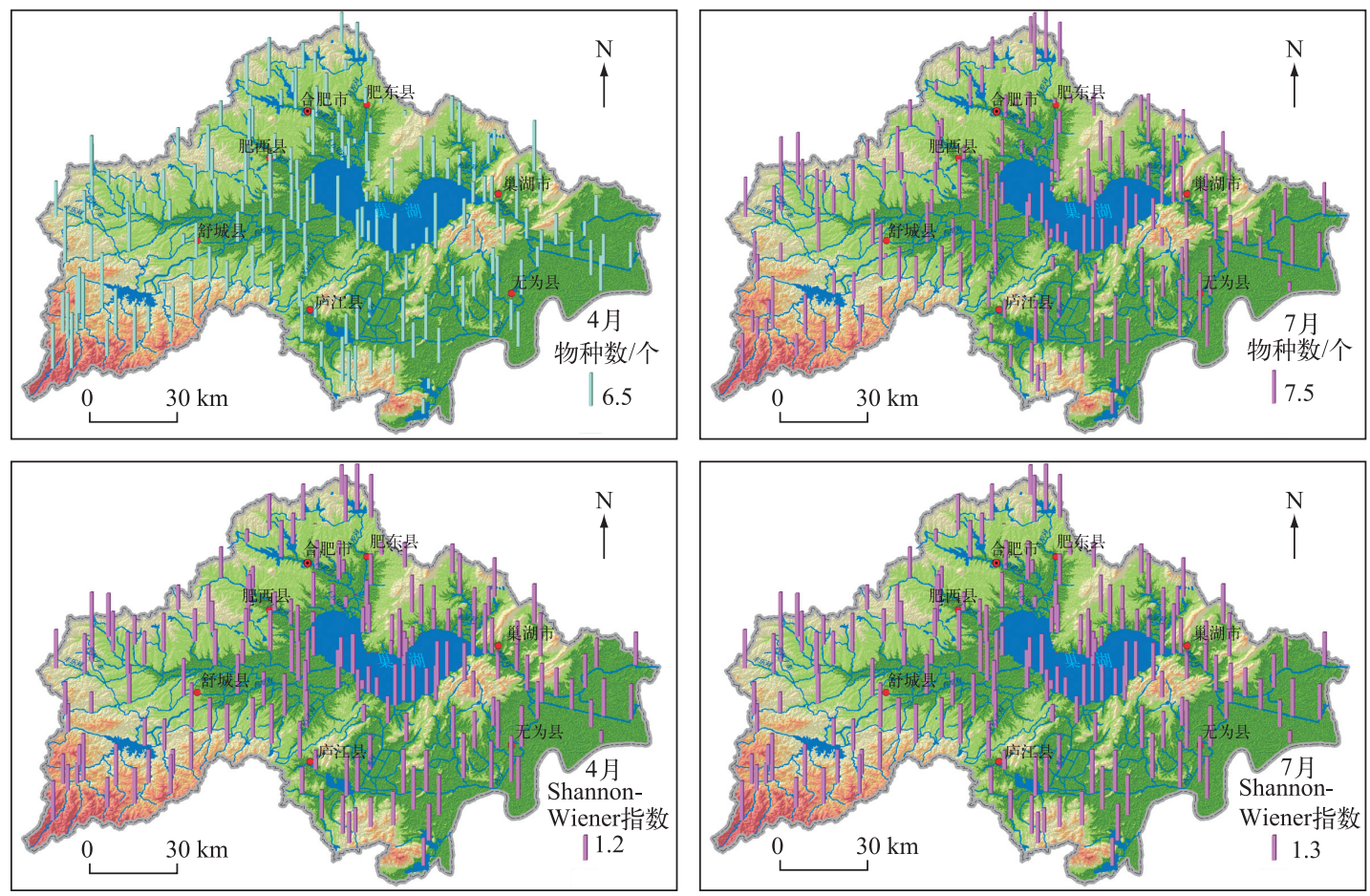

图 2 巢湖流域水生植物物种多样性空间分布格局

Fig.2 Spatial distribution patterns of species diversity of aquatic plants in Chaohu Basin

各样点水生植物物种丰富度指数的平均值在 3.962 8.200 之间, 以白石天河流域 ( I ) 内水生植物物种丰富 度指数平均值最高为 8.200 , 其次是杭埠河丰乐河流域 (IV) 为 7.098 , 巢湖湖滨带 (II) 和店埠河南淝河流域 (III) 水生植物物种丰富度指数相对较低, 分别是 4.400 和 3.962 , 均显著低于石天河流域的物种丰富度指数 $(P<0.05)$.

8 个主要区域 4 月水生植物 Shannon-Wiener 多样性指数在 $1.041 \sim 1.927$ 之间, Simpson 优势度指数在 0.526 0.832 之间, Shannon-Wiener 指数和 Simpson 指数在巢湖湖滨带和 7 个主要流域之间的差异性与物种 丰富度比较相似, 都是白石天河流域 Shannon-Wiener 指数和 Simpson 指数指数最大, 分别是 1.927 和 0.832 , 杭埠河丰乐河流域 (IV) Shannon-Wiener 指数次之为 1.689 , 兆河流域 (VII) Simpson 指数指数次之为 0.758 , 店 埠河南淝河流域 (III) Shannon-Wiener 指数和 Simpson 指数最小, 分别是 1.041 和 0.526 ; 白石天河流域 Shannon-Wiener 指数和 Simpson 指数指数显著大于巢湖湖滨带 ( II ) 和店埠河南淝河流域 ( III) 的 Shannon-Wiener 指数和 Simpson 指数 $(P<0.05)$.

4 月 Pielou 均匀度指数在 8 个主要区域之间没有显著性差异 $(P>0.05)$, 但也是以白石天河流域 ( I ) 均 匀度指数最高为 0.931 , 兆河流域 (VII) 次之为 0.904 , 巢湖湖滨带 (II) 和店埠河南淝河流域 ( III) 相对较低, 分别是 0.705 和 0.688 .

调查发现, 巢湖流域 8 个主要区域 7 月水生植物物种多样性差异非常明显(图 4), 水生植物物种数在不 同流域中变化较大, 8 个主要区域内样点水生植物物种丰富度指数的平均值在 4.333 9.000 之间, 以白石天 河流域 ( I ) 内水生植物物种丰富度指数最高 (为 9.000), 其次是柘臬河夏阁河流域 (VIII) (为 8.375 ), 巢湖湖 滨带 (II) 和派河流域 ( V) 水生植物物种丰富度指数相对较低, 分别为 4.438 和 4.333 , 均显著低于白石天河 和柘臬河夏阁河流域的物种丰富度指数 $(P<0.05)$.

7 月巢湖流域 8 个主要区域水生植物 Shannon-Wiener 多样性指数在 1.096 1.974 之间,Simpson 优势度 指数在 $0.533 \sim 0.833$ 之间. 与 4 月调查结果相似, 7 月 Shannon-Wiener 指数以白石天河流域最高 (为 1.974 ), 

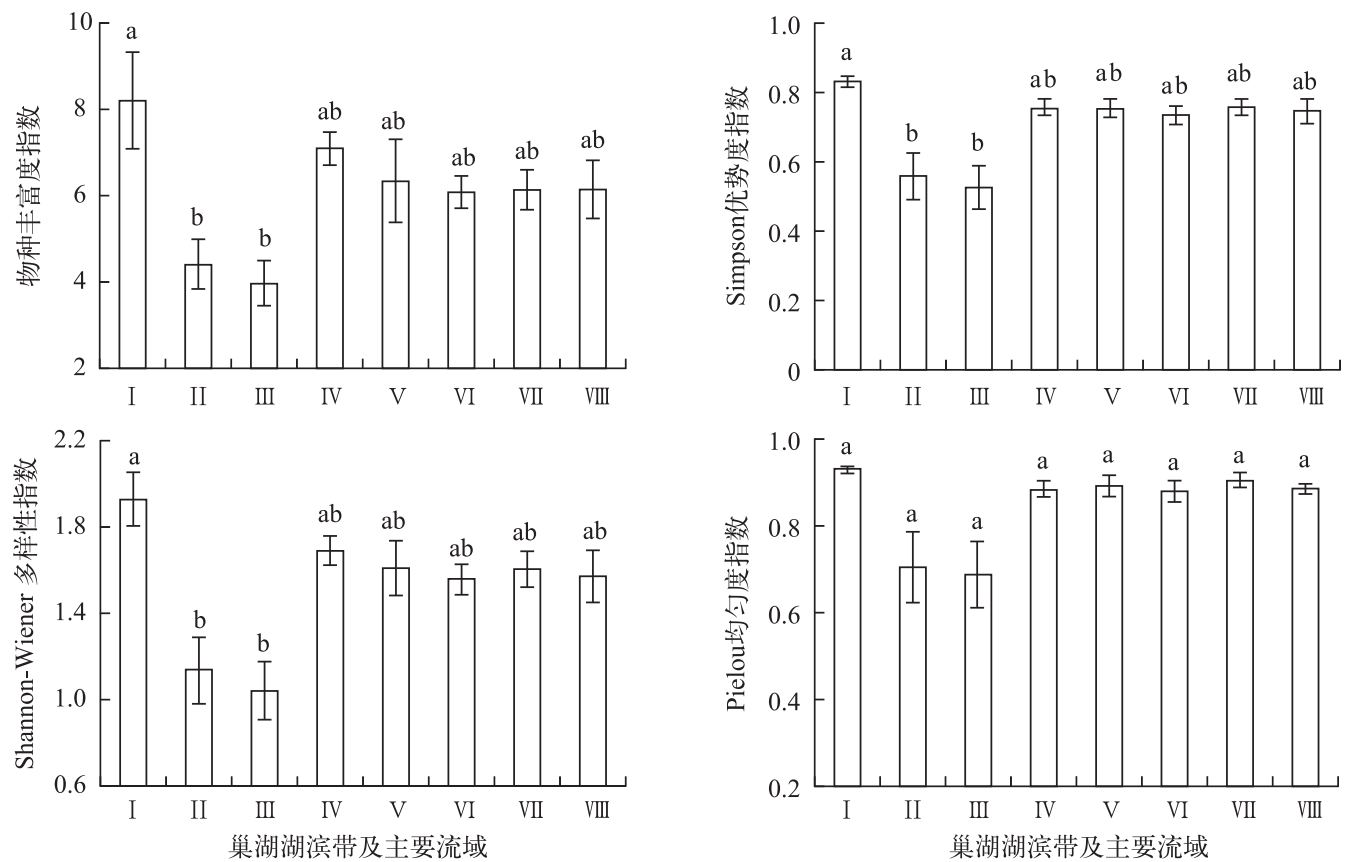

图 3 巢湖湖滨带及主要流域 4 月水生植物多样性(不同小写字母代表差异显著 $(P<0.05)$,下同)

Fig.3 The species diversity of aquatic plants in April in riparian zone of Lake Chaohu and its main basins

其次是柘臬河夏阁河流域 (为 1.846), 巢湖湖滨带、店埠河南汁河流域和派河流域 Shannon-Wiener 指数值相 对较低, 分别是 $1.096 、 1.168$ 和 1.222, 均显著低于白石天河流域 Shannon-Wiener 指数值 $(P<0.05)$; 7 月 Simpson 指数也是以白石天河流域最高 (为 0.833$)$, 显著高于巢湖湖滨带 Simpson 指数值 $(0.533)(P<0.05)$ 和店 埠河南淝河流域 Simpson 指数值 $(0.544)(P<0.05)$.

7 月 Pielou 均匀度指数在 8 个主要区域之间没有显著性差异 $(P>0.05)$, 但以白石天河流域 $(\mathrm{I})$ 均匀度 指数最高 (为 0.905 ), 柘臬河夏阁河流域 (VIII) 次之 (为 0.883 ), 巢湖湖滨带 (II ) 和店埠河南淝河流域 (III) 相对较低,分别为 0.717 和 0.682 .

\section{3 讨论}

对巢湖流域水生植物群落物种组成及多样性进行分析和研究, 结果表明巢湖流域共有水生植物 43 科 85 属 123 种, 其中蓱类植物有 5 科 6 属 6 种, 被子植物 38 科 77 属 117 种; 巢湖流域水生植物含属数或种数 较多的科主要包括禾本科、苶科、莎草科、菊科、眼子菜科等; 属的组成比较分散,塞种属 ( $2 \sim 4$ 种) 和单种属 共 82 个,含 103 种, 占总属数的 $96.5 \%$ 和总种数的 $83.8 \%$; 水生植物中优势种主要包括喜早莲子草、芦苇、菹 草、菱、金鱼藻、曧草、黑藻等,同时有近 $35 \%$ 的物种在调查中仅出现过 $1 \sim 2$ 次. 从水生植物分布区类型看,在 科级水平上有 6 个分布区类型, 科的分布区类型以世界广布最多,有 24 个科; 在属级水平上有 13 个分布区 类型,属的分布区类型以世界广布最多,有 31 个属.

通过对巢湖流域不同子流域及湖滨带水生植物群落物种多样性的研究发现,物种多样性指数以白石天 河流域最高,杭埠河丰乐河流域次之, 店埠河南淝河最低. 白石天河流域和杭埠河丰乐河流域位于巢湖流域 的西部丘陵区域,受人类活动干扰较小, 南汁河是合肥主城区最大的巢湖人湖河流, 水质及底泥污染严

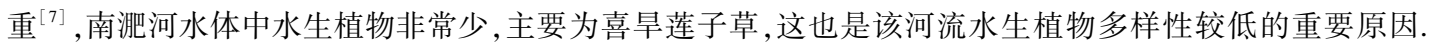
调查发现,巢湖湖体 (湖滨带) 共有水生植物 53 种, 隶属于 27 科 42 属, 其中沉水植物共 7 种. 目前, 巢湖沉 水植物的面积极小, 湖心地带几乎无沉水植物分布, 沉水植被仅限于沿岸带分布. 竹叶眼子菜是巢湖沉水植 物的优势种, 在其生长区域伴有少量其他沉水植物或浮叶植物生长, 如穗花狐尾藻、金鱼藻、菱和荢菜等, 在 

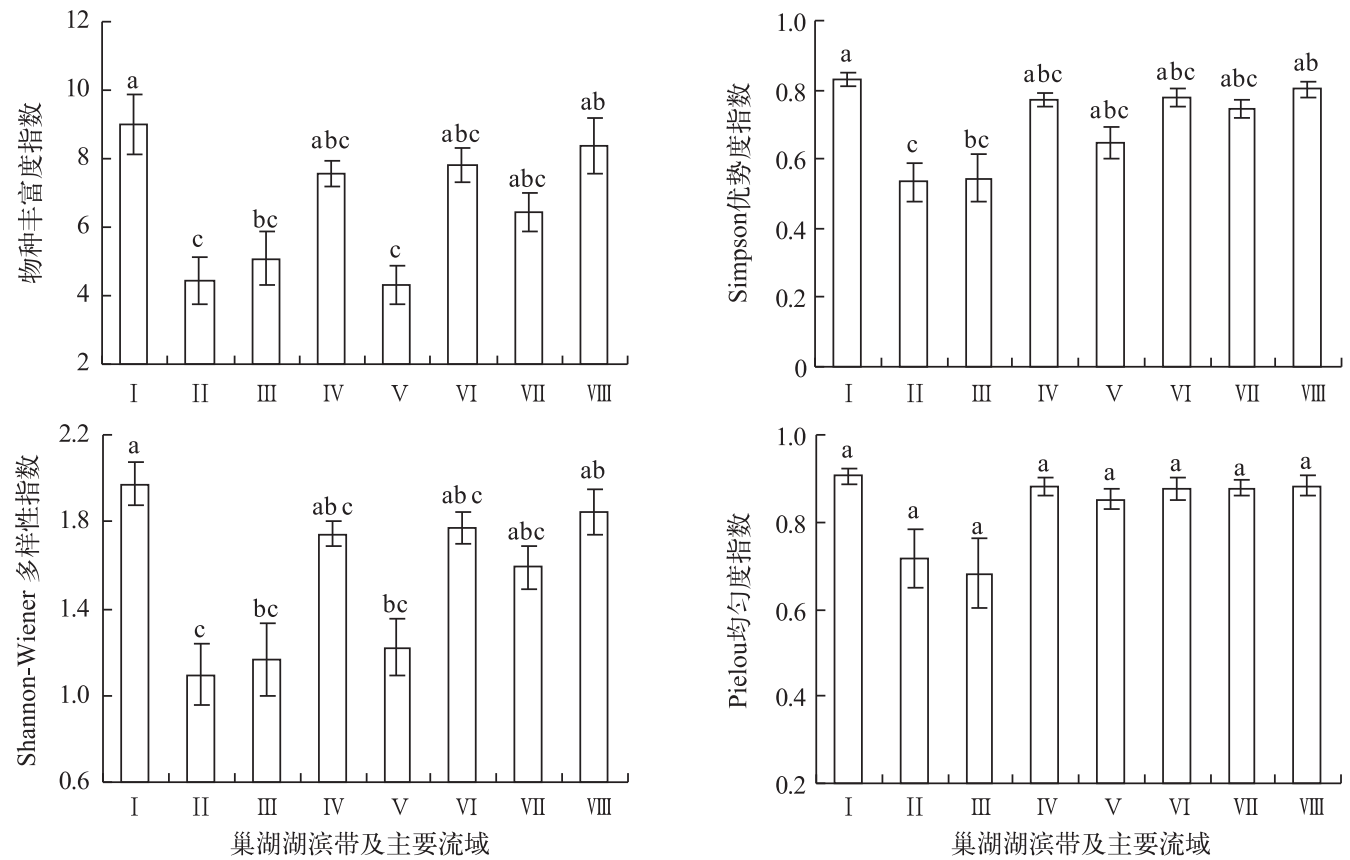

图 4 巢湖湖滨带及主要流域 7 月水生植物多样性

Fig.4 The species diversity of aquatic plants in July in riparian zone of Lake Chaohu and its main basins

巢湖湖滨带部分区域的外围分布有较大面积的挺水植物, 如芦苇和香蒲等. 1980s 调查发现, 巢湖水生植被 分布面积约占该湖总面积的 $2.54 \%$, 以䓚草和竹叶眼子菜为优势种, 前者分布面积约为后者的 3 倍, 此外还 分布有较多的黑藻群落和苦草群落. 2010 年调查发现巢湖沉水植物中竹叶眼子菜为巢湖沉水植被的单一优 势种, 此时水生植被分布面积仅为全湖面积的 $1.54 \%$, 竹叶眼子菜的分布面积占沉水植物分布总面积的 $90.7 \%$, 黑藻、苦草等环境敏感型的水生植物非常稀少, 已濒临消失 ${ }^{[10,20]}$. 此次调查也发现竹叶眼子菜已经取 代蕰草成为巢湖沉水植被的主要优势种, 且蕰草在 4 月巢湖湖体中也分布很少, 其它水生植物如黑藻、苦草 已难受踪迹. 可以看出, 随着近几十年巢湖湖体水质变差及富营养化的日益严重, 耐污性较强的竹叶眼子菜 已成为巢湖沉水植被的绝对优势种, 耐污能力弱的苦草、黑藻等已逐渐消失. 若巢湖水质不能得到有效改 善, 竹叶眼子菜作为巢湖沉水植被的单一优势种的现状可能还会将存在一段时间, 沉水植物的种类和生物 量也可能会逐渐减少.

本次调查发现,外来人侵植物喜旱莲子草在东部平原区流域内很多水体中都有分布,在部分水体中甚 至成为单一优势种,严重影响本土水生植物的生存空间. 此外,钻叶紫苑等外来人侵植物在局部水域也已严 重影响其他物种的生存,减小了水生植物的多样性.

\section{4 参考文献}

[ 1 ] Gao Feng, Yin Hongbin, Hu Weiping et al. Ecological characteristics of macrobenthos communities in Chaohu basin in spring and their relationships with environmental factors. Chinese Journal of Applied Ecology, 2010, 21( 8) : 2132-2139. [ 高峰, 尹洪斌, 胡维平等. 巢湖流域春季大型底栖动物群落生态特征及与环境因子关系. 应用生态学报, 2010, 21 (8) : 2132-2139.]

[ 2 ] Ning Yi, Gao Feng, Deng Jiancai et al. Biological assessment of water quality in Chaohu Lake watershed: A case study of benthic macroinvertebrate. Chinese Journal of Ecology, 2012, 31(4): 916-922. [宁怡, 高峰, 邓建才等. 巢湖流域水 质生物学评价——以大型底栖动物为例. 生态学杂志, 2012, 31(4) : 916-922.]

[ 3 ] Lu Na, Yin Hongbin, Deng Jiancai et al. Spring community structure of phytoplankton from Lake Chaohu and its relation- 
ship to environmental factors. J Lake Sci, 2010, 22(6) : 950-956. DOI: 10.18307/2010.0620. [ 路娜, 尹洪斌, 邓建才 等. 巢湖流域春季浮游植物群落结构特征及其与环境因子的关系. 湖泊科学, 2010, 22(6): 950-956.]

[ 4 ] Wang Chunjing, Zhou Shoubiao, Yang Haijun et al. Diversity of aquatic vascular plants in Anhui Province. Journal of Nanjing Forestry University: Natural Sciences, 2006, 30(5): 87-90. [王春景, 周守标, 杨海军等. 安徽水生维管植物 的多样性. 南京林业大学学报: 自然科学版, 2006, 30(5): 87-90.]

[ 5 ] Liu Kun, Dai Junxian, Tang Chengfeng et al. Diversity of vascular plant and classification system of vegetation in wetlandsof Anhui Province. Acta Ecologica Sinica, 2014, 34(19): 5434-5444. [刘坤, 戴俊贤, 唐成丰等. 安徽湿地维管植物 多样性及植被分类系统. 生态学报, 2014, 34(19) : 5434-5444.]

[6] Ji Lan, Yang Liwu, Li Jing. Study on pollution situation of Nanfeihe river and strategies of substainable development. Journal of Anhui University: Natural Sciences, 2006, 30(4): 91-94. [纪岗, 杨立武, 李菁. 南淝河水污染现状与可持续 发展对策研究. 安徽大学学报: 自然科学版, 2006, 30(4) : 91-94.]

[ 7 ] Li Zhu, Guo Weijie, Cheng Shuiping et al. The spatial and temporal distribution of chlorophylla and its correlation with environmental factors in the Nanfeihe river. Acta Hydrobiologica Sinica, 2014, 38(2): 342-350. [李柱, 郭伟杰, 成水平 等. 南淝河叶绿素 a 时空分布特征及环境因子影响分析. 水生生物学报, 2014, 38(2) : 342-350. ]

[ 8 ] Zhu Guorong, Ni Leyi, Fang Tao et al. Community structure and floristic compositions of aquatic plant communities in the inflowing rivers of east Chaohu lake and their relationships to environmental factors. Chinese Journal of Apply Environmental Biology, 2012, 18(6) : 889-896. [祝国荣, 倪乐意, 方涛等. 巢湖东湖区人湖河流的水生植被群落结构和区系特 征及其与环境因子的关系. 应用与环境生物学报, 2012, 18(6) : 889-896.]

[ 9 ] Pan Guolin, Hong Tianqiu, Zheng Wei et al. Analysis of diversity of the plant community in estuary wetland of the Shiwulihe River in the basin of the Chaohu Lake. Journal of Hefei University of Technology: Natural Science, 2007, 30(10): 1237-1240. [潘国林, 洪天求, 郑伟等. 巢湖十五里河河口湿地植物群落多样性分析. 合肥工业大学学报: 自然科 学版, 2007, 30(10): 1237-1240.]

[10] Hao Beibei, Wu Haoping, Liu Wenzhi et al. Vegetation features and degradation causes in Chaohu lakeshore zone. Environmental Science and Management, 2013, 38(6) : 59-65. [ 郝贝贝, 吴吴平, 刘文治等. 巢湖湖滨带植被特征及其退 化原因分析研究. 环境科学与管理, 2013,38(6): 59-65.]

[11] Cook CDK, Gut BJ, Rix FM et al eds. Water plants of the world. Hague: W. Junk, 1974: 37-89.

[12] Lü Xianguo ed. Wetland ecosystem observation methods. Beijing: China Environmental Science Press, 2005. [吕宪国. 湿 地生态系统观测方法. 北京: 中国环境科学出版社, 2005.]

[13] Wu Zhonghua, Yu Dan, Wang Dong et al. Structure and quantitative features of aquatic plant communities in the Hanjiang River. Acta Phytoecologica Sinica, 2003, 27(1): 118-124. [吴中华, 于丹, 王东等. 汉江水生植物群落的结构与数 量特征. 植物生态学报, 2003, 27(1): 118-124.]

[14] Cui Xinhong, Chen Jiakuan, Li Wei. Survey methods on aquatic macrophyte vegetation in lakes in the middle and lower reaches of Changjiang River. Journal of Wuhan Botanical Research, 1999, 17(4): 357-361. [崔心红, 陈家宽, 李伟. 长江中下游湖泊水生植被调查方法. 武汉植物学研究, 1999, 17(4): 357-361.]

[15] FangJingyun, Wang Xiangping, Shen Zehao et al. Methods and protocols for plant community inventory. Biodiversity Science, 2009, 17(6) : 533-548. [方精云, 王襄平, 沈泽吴等. 物群落清查的主要内容、方法和技术规范. 生物多样 性, 2009, 17(6): 533-548.]

[16] Lou Yanjing, Zhao Kuiyi, Ma Keping. Change in floristic composition and species diversity of plant community along environment gradient in Honghe National Nature Reserve, China. Acta Ecologica Sinica, 2007, 27(9) : 3883-3891. [娄彦 景, 赵鬼义, 马克平. 洪河自然保护区典型湿地植物群落组成及物种多样性梯度变化. 生态学报, 2007, 27(9): 3883-3891.]

[17] Wu Zhengyi, Zhou Zhekun, Li Dezhu et al. The areal-types of the world families of seed plants. Acta Botanica Yunnanica, 2003,25 (3) : 245-257. [ 吴征镒, 周浙昆, 李德铢等. 世界种子植物科的分布区类型系统. 云南植物研究, 2003, $25(3): 245-257$.

[18] Flora of China Editorial Committee ed. The Flora of China: Volume 1. Beijing: Science Press, 2004. [中国科学院《中国 植物志》编辑委员会. 中国植物志: 第 1 卷. 北京: 科学出版社, 2004.]

[19] Wu Zhengyi, Zhou Zhekun, Sun Hang et al. The areal-types of seed plants and their origin and differentiation. Kunming: Yunnan Science and Technology Press, 2006. [ 吴征镒, 周浙昆, 孙航等. 种子植物分布区类型及其起源与分化. 昆 
明: 云南科技出版社, 2006. ]

[20] Ren Yanqin, Chen Kaining. Status of submerged macrophytes and its relationship with environmental factors in Lake Chaohu. J Lake Sci, 2010, 23(3) : 409-416. DOI: 10.18307/2011.0314. [任艳芹, 陈开宁. 巢湖沉水植物现状 (2010 年) 及其与环境因子的关系. 湖泊科学, 2010, 23(3): 409-416.]

附录 巢湖流域水生植物物种统计

Supplement Aquatic plants species checklist in Chaohu Basin

\begin{tabular}{|c|c|c|c|}
\hline \multirow{2}{*}{ 科名 } & \multirow{2}{*}{ 种名 } & \multicolumn{2}{|c|}{ 出现样点数 } \\
\hline & & 4 月 & 7 月 \\
\hline \multirow[t]{2}{*}{ 木贼科 Equisetaceae } & 问荆 Equisetum arvense & 2 & - \\
\hline & 节节草 E. ramosissimum & 1 & - \\
\hline 水蕨科 Parkeriaceae & 水蕨 Ceratopteris thalictroides & - & 1 \\
\hline 苹科 Marsileaceae & 苹 Marsilea quadrifolia & 8 & 12 \\
\hline 槐叶苹科 Salviniaceae & 槐叶苹 Salvinia natans & 2 & 29 \\
\hline 满江红科 Azollaceae & 满江红 Azolla imbricata & 2 & 11 \\
\hline \multirow[t]{12}{*}{ 蓼科 Polygonaceae } & 酸模叶苶 Polygonum lapathifolium & 2 & 18 \\
\hline & 绵毛酸模叶苶 P. lapathifolium var. salicifolium & - & 8 \\
\hline & 荭苶 $P$. orientale & 1 & 10 \\
\hline & 水蓼 P. hydropiper & 23 & 39 \\
\hline & 愉悦苶 $P$. jucundum & - & 1 \\
\hline & 苶子草 $P$. criopolitanum & 3 & - \\
\hline & 戟叶蓼 P. thunbergii & 4 & 2 \\
\hline & 箭叶蓼 P. sieboldii & 2 & 10 \\
\hline & 长戟叶蓼 P. maackianum & - & 1 \\
\hline & 细叶苶 P. taquetii & - & 3 \\
\hline & 齿果酸模 Rumex dentatus & 21 & - \\
\hline & 羊蹄 $R$. japonicus & 21 & 1 \\
\hline \multirow[t]{3}{*}{ 石竹科 Caryophyllaceae } & 繁缕 Stellaria media & 8 & - \\
\hline & 中国繁缕 S. chinensis & 3 & - \\
\hline & 牛繁缕 Myosoton aquaticum & 1 & - \\
\hline \multirow[t]{2}{*}{ 苋科 Amaranthaceae } & 喜早莲子草 Alternanthera philoxeroides & 111 & 133 \\
\hline & 莲子草 $A$. sessilis & - & 2 \\
\hline \multirow[t]{5}{*}{ 毛莨科 Ranunculaceae } & 石龙芮 Ranunculus sceleratus & 16 & - \\
\hline & 刺果毛莨 R. muricatus & 10 & - \\
\hline & 毛莨 $R$. japonicus & 4 & 1 \\
\hline & 肉根毛莨 $R$. polii & 1 & - \\
\hline & 水毛莨 Batrachium bungei & - & 3 \\
\hline 三白草科 Saururaceae & 三白草 Saururus chinensis & 2 & 1 \\
\hline \multirow[t]{2}{*}{ 睡莲科 Nymphaeaceae } & 莲 Nelumbo nucifera & 1 & 1 \\
\hline & 苂 Euryale ferox & - & 1 \\
\hline 金鱼藻科 Ceratophvllaceae & 金鱼藻 Ceratophyllum demersum & 44 & 75 \\
\hline \multirow[t]{6}{*}{ 十字花科 Cruciferae } & 碎米荠 Cardamine hirsuta & 14 & - \\
\hline & 水田碎米荠 C. lyrata & 2 & - \\
\hline & 广东蔊菜 Rorippa cantoniensis & 1 & - \\
\hline & 球果蔊菜 $R$. globosa & 2 & - \\
\hline & 印度草菜 $R$. indica & 4 & - \\
\hline & 荠菜 Capsella bursa-pastoris & 3 & - \\
\hline 虎耳草科 Saxifragaceae & 扯根菜 Penthorum chinense & - & 7 \\
\hline
\end{tabular}


续附表

\begin{tabular}{|c|c|c|c|}
\hline \multirow{2}{*}{ 科名 } & \multirow{2}{*}{ 种名 } & \multicolumn{2}{|c|}{ 出现样点数 } \\
\hline & & 4 月 & 7 月 \\
\hline 苗薇科 Rosaceae & 朝天委陵菜 Potentilla supina & 2 & - \\
\hline 葫芦科 Cucurbitaceae & 盒子草 Actinostemma tenerum & 5 & - \\
\hline 千屈菜科 Lythraceae & 圆叶节节菜 Rotala rotundifolia & 1 & - \\
\hline \multirow[t]{5}{*}{ 菱科 Trapaceae } & 菱 Trapa bispinosa & 29 & 40 \\
\hline & 四角菱 T. quadrispinosa & - & 1 \\
\hline & 细果野菱 T. maximowiczii & - & 2 \\
\hline & 野菱 $T$. incisa & - & 6 \\
\hline & 乌菱 $T$. bicornis & - & 18 \\
\hline \multirow[t]{2}{*}{ 柳叶菜科 Onagraceae } & 丁香蓼 Ludwigia prostrata & - & 1 \\
\hline & 黄花水龙 L. peploides subp. stipulacea & - & 3 \\
\hline 小二仙草科 Haloragidaceae & 穗状狐尾藻 Myriophyllum spicatum & 60 & 40 \\
\hline \multirow[t]{2}{*}{ 伞形科 Umbelliferae } & 水芹 Oenanthe javanica & 32 & 18 \\
\hline & 破铜钱 Hydrocotyle sibthorpioides var. batrachium & 4 & 1 \\
\hline 报春花科 Primulaceae & 泽珍珠菜 Lysimachia candida & 10 & 1 \\
\hline \multirow[t]{2}{*}{ 睡菜科 Menyanthaceae } & 荢菜 Nymphoides peltatum & 17 & 9 \\
\hline & 金银莲花 $N$. indica & - & 3 \\
\hline \multirow[t]{3}{*}{ 唇形科 Labiatae } & 活血丹 Glechoma longituba & 2 & - \\
\hline & 薄荷 Mentha haplocalyx & 3 & 2 \\
\hline & 溪黄草 Isodon serra & 6 & 3 \\
\hline 马鞭草科 Verbenaceae & 过江藤 Phyla nodiflora & - & 1 \\
\hline 爵床科 Acanthaceae & 水蓑衣 Hygrophila salicifolia & - & 2 \\
\hline \multirow[t]{2}{*}{ 玄参科 Scrophulariaceae } & 北水苦荬 Veronica anagallis-aquatica & 16 & - \\
\hline & 通泉草 Mazus japonicus & 5 & - \\
\hline 胡麻科 Pedaliaceae & 茶菱 Trapella sinensis & - & 8 \\
\hline 狸藻科 Lentibulariaceae & 黄花狸藻 Utricularia aurea & 2 & 11 \\
\hline \multirow[t]{5}{*}{ 菊科 Compositae } & 马兰 Kalimeris indica & 4 & - \\
\hline & 虾须草 Sheareria nana & 1 & 10 \\
\hline & 萎蒿 Artemisia selengensis & 9 & 5 \\
\hline & 钻叶紫苑 Aster subulatus & 2 & - \\
\hline & 醴肠 Eclipta prostrata & - & 1 \\
\hline 泽泻科 Alismataceae & 慈菇 Sagittaria trifolia & - & 2 \\
\hline \multirow[t]{4}{*}{ 水鳖科 Hydrocbadtaceae } & 黑藻 Hydrilla verticillata & 20 & 43 \\
\hline & 水鳖 Hydrocharis dubia & 15 & 46 \\
\hline & 苦草 Vallisneria natans & 6 & 30 \\
\hline & 水车前 Ottelia alismoides & - & 1 \\
\hline \multirow[t]{5}{*}{ 眼子菜科 Potamogetonaceae } & 眼子菜 Potamogeton distinctus & 11 & - \\
\hline & 竹叶眼子菜 P. malaianus & 10 & 28 \\
\hline & 微齿眼子菜 P. maackianus & 12 & 15 \\
\hline & 菹草 P. crispus & 79 & 19 \\
\hline & 尖叶眼子菜 P. oxyphyllus & - & 1 \\
\hline \multirow[t]{3}{*}{ 茨藻科 Najadaeeae } & 小茨藻 Najas minor & - & 5 \\
\hline & 大茨藻 N. marina & 1 & 1 \\
\hline & 草茨藻 $N$. graminea & - & 1 \\
\hline 雨久花科 Pontederiaceae & 凤眼莲 Eichhornia crassipes & - & 1 \\
\hline 灯心草科 Juncaceae & 灯心草 Juncus effusus & 17 & 8 \\
\hline
\end{tabular}


续附表

\begin{tabular}{|c|c|c|c|}
\hline \multirow{2}{*}{ 科名 } & \multirow{2}{*}{ 种名 } & \multicolumn{2}{|c|}{ 出现样点数 } \\
\hline & & 4 月 & 7 月 \\
\hline \multirow[t]{2}{*}{ 鸭跖草科 Commelinaceae } & 鸭跖草 Commelina communis & - & 3 \\
\hline & 水竹叶 Murdannia triquetra & - & 8 \\
\hline 谷精草科 Eriocaulaceae & 谷精草 Eriocaulon buergerianum & - & 1 \\
\hline \multirow[t]{19}{*}{ 禾本科 Gramineae } & 菰 Zizania latifolia & 13 & 26 \\
\hline & 芦苇 Phragmites australis & 67 & 74 \\
\hline & 芦竹 Arundo donax & 3 & 2 \\
\hline & 早熟禾 Poa апnиа & 1 & - \\
\hline & 光头稗 Echinochloa colona & - & 21 \\
\hline & 长芒稗 E. caudata & - & 11 \\
\hline & 狗牙根 Cynodon dactylon & 3 & - \\
\hline & 马唐 Digitaria sanguinalis & 1 & - \\
\hline & 假稻 Leersia japonica & 9 & 15 \\
\hline & 水禾 Hygroryza aristata & - & 1 \\
\hline & 牛鞭草 Hemarthria altissima & - & 7 \\
\hline & 狗尾草 Setaria viridis & - & 1 \\
\hline & 荩草 Arthraxon hispidus & - & 5 \\
\hline & 虉草 Phalaris arundinacea & 33 & 34 \\
\hline & 看麦娘 Alopecurus aequalis & 3 & - \\
\hline & 菌草 Beckmannia syzigachn & 3 & - \\
\hline & 双穗雀稗 Paspalum distichum & 42 & 66 \\
\hline & 鹅观草 Roegneria kamoji & 5 & 1 \\
\hline & 荻 Triarrhena sacchariflora & - & 11 \\
\hline \multirow[t]{3}{*}{ 天南星科 Araceae } & 菖蒲 Acorus calamus & - & 11 \\
\hline & 石菖蒲 A. tatarinowii & 9 & 14 \\
\hline & 芋 Colocasia esculenta & 1 & - \\
\hline \multirow[t]{2}{*}{ 浮萍科 Lemnaeeae } & 紫萍 Spirodela polyrrhiza & - & 56 \\
\hline & 浮萍 Lemna minor & 21 & 23 \\
\hline \multirow[t]{2}{*}{ 香蒲科 Typhaceae } & 香蒲 Typha orientalis & 21 & 14 \\
\hline & 水烛 $T$. angustifolia & 9 & 5 \\
\hline \multirow[t]{10}{*}{ 莎草科 Cyperaceae } & 水葱 Scirpus validus & - & 1 \\
\hline & 蔍草 S. triqueter & 1 & - \\
\hline & 香附子 Cyperus rotundus & 5 & 1 \\
\hline & 聚穗莎草 $C$. glomeratus & - & 1 \\
\hline & 高杆莎草 C. exaltatus & - & 2 \\
\hline & 碎米莎草 C. iria & - & 2 \\
\hline & 垂穗荎草 Carex dimorpholepis & - & 14 \\
\hline & 陌上菅 C. thunbergii & 10 & 2 \\
\hline & 牛毛段 Eleocharis yokoscensis & 2 & - \\
\hline & 具槽稈荣荠 E. valleculosa & - & 1 \\
\hline
\end{tabular}

